\title{
Hexavalent Chromium Removal from Water Using Heat-Acid Activated Red Mud
}

\author{
Min Ma1, Yifeng Lu1 ${ }^{*}$, Rongzhi Chen ${ }^{2 *}$, Lan Ma ${ }^{3}$, Ying Wang1 \\ ${ }^{1}$ School of Life Sciences, Yunnan University, Kunming China \\ ${ }^{2}$ College of Resources and Environment, University of Chinese Academy of Sciences, Beijing, China \\ ${ }^{3}$ Yunnan Academies of Science and Technology Development, Kunming, China \\ Email: ${ }^{*}$ Iyftoday@126.com, ${ }^{*}$ crz0718@hotmail.com
}

Received 2 March 2014; revised 5 April 2014; accepted 12 April 2014

Copyright (C) 2014 by authors and Scientific Research Publishing Inc.

This work is licensed under the Creative Commons Attribution International License (CC BY).

http://creativecommons.org/licenses/by/4.0/

(c) (i) Open Access

\section{Abstract}

This study investigated the heat-acid activated red mud used for hexavalent chromium $\left(\mathrm{Cr}^{6+}\right)$ removal from aqueous solution. The results showed that the heat-acid activated red mud enhanced hexavalent chromium removal capacity from 0.003 to $0.015 \mathrm{mg} \cdot \mathrm{g}^{-1}$. Adsorption experiments were conducted as a function of adsorbent dosage, contact time, $\mathrm{pH}$ and reaction temperature. The removal efficiency was found to increase gradually when solution $\mathrm{pH}$ decreased and maximum removal was achieved at $\mathrm{pH} 2$. The physico-chemical characteristics of heat-acid activated red mud were studied by using instrumental technique like Scanning Electron Microscope (SEM), X-ray diffraction (XRD) and X-ray fluorescence spectrometry (XRF). The experimental data fitted well to Langmuir isotherm model. Thermodynamic parameters indicated the adsorption process was exothermic reaction. The cost-effective performance and, simple operation suggest the heat-acid activated red mud can be taken as a promising sorbents for removal of $\mathrm{Cr}^{6+}$ from wastewater.

\section{Keywords}

Red Mud, Heat-Acid Treatment, Adsorption Isotherm, Hexavalent Chromium Removal

\section{Introduction}

Hexavalent chromium is one of the heavy mental contaminants found in the water which is used in a variety of applications including electroplating, steel production, leather tanning, mining and textile dyeing [1]. Chromium usually exists in both trivalent and hexavalent forms in water, and trivalent chromium is an essential trace element for human and plays a vital role in normal carbohydrate, lipid and protein metabolism [2]. It is poisonous

${ }^{*}$ Corresponding authors.

How to cite this paper: Ma, M., et al. (2014) Hexavalent Chromium Removal from Water Using Heat-Acid Activated Red Mud. Open Journal of Applied Sciences, 4, 275-284. http://dx.doi.org/10.4236/ojapps.2014.45027 
only at high concentration [3]. Hexavalent chromiumis highly toxic, it can cause diseases like dermatitis, damage to liver, kidney circulation, lung cancer and even death [4]. According to the recommendation of The World Health Organization (WHO), the maximum allowable limit for total chromium in drinking water is at the level of $0.05 \mathrm{mg} \cdot \mathrm{L}^{-1}[5]$.

Many methods have been reported for hexavalent chromium removal such as chemical precipitation [6], membrane filtration [7], ion exchange [8], electrolytic [9] and adsorption [10]. Among all the above mentioned methods, adsorption is a promising method due to its high efficient, low cost, flexibility and simplicity of design, ease of operation, avoiding the formation of secondary pollutants and so on. A variety of materials have used as hexavalent chromium sorbents, including activated carbon, zeolite, bentonite, biological materials, fly ash, red mud and others [11]-[16].

Red mud (RM) emerges as a waste by-product during the alkaline leaching of bauxite in the Bayer process. Owing to its chemical stability and structural properties, RM has been found to remove heavy metals, phosphate [17], dyes [18] from aqueous solution. In the present work an attempt has been made to use the acidified red mud (ARM) as an adsorbent for the removal of hexavalent chromium from model aqueous solution, to investigate the effect of contact time, initial solution $\mathrm{pH}$ and temperature on the adsorption, and to discuss the adsorption isotherm of ARM for hexavalent chromium.

\section{Experimental}

\subsection{Adsorbent Preparation}

The RM sample used in this study was obtained from Wenshan Aluminum Industry Corporation, Yunnan province, China. The chemical composition of $\mathrm{RM}$ is: $\mathrm{SiO}_{2}$ (17.56\%), $\mathrm{Fe}_{2} \mathrm{O}_{3}$ (34.33\%), $\mathrm{Al}_{2} \mathrm{O}_{3}(17.09 \%), \mathrm{CaO}$ (16.84\%), $\mathrm{MgO}(0.46 \%), \mathrm{K}_{2} \mathrm{O}(0.04 \%)$ and $\mathrm{Na}_{2} \mathrm{O}(2.88 \%)$.

The RM is screened through a 100 mesh screen and dried at $105^{\circ} \mathrm{C}$. RM was boiled in $0.5 \mathrm{M} \mathrm{HCl}$ solution for $2 \mathrm{~h}$ at $80^{\circ} \mathrm{C}$, the ratio of liquid to solid was $20 \mathrm{mg} \cdot \mathrm{L}^{-1}$. Finally, the acidified ARM samples were heated at $105^{\circ} \mathrm{C}$ to get constant weight and stored in the valve bag for further study [19].

\subsection{Characterization of the Adsorbent}

The surface morphology of RM before and after modification was observed by a scanning electron microscopy performed using a FEI Quanta 200 electron microscopy (Holland). X-ray fluorescence spectrometry (XRF, ZSX100e, Japan) has been used for analysis the elemental change of RM before and after modification. X-ray diffraction (XRD, TTR111, Japan) measurements were used nickel filtered $\mathrm{Cu}$ Ka radiation (40 KV, $20 \mathrm{~mA})$. The patterns are recorded in the $2 \theta$ range $10^{\circ}-70^{\circ}$ with a scanning speed of $30^{\circ} \mathrm{min}^{-1}$.

\subsection{Hexavalent Chromium Adsorption Experiments}

A stock solution (100 mg $\cdot \mathrm{L}^{-1}$ ) of hexavalent chromium was prepared by dissolving analytical grade $\mathrm{K}_{2} \mathrm{Cr}_{2} \mathrm{O}_{7}$ into distilled water. The test solution of hexavalent chromium used in each study was prepared by diluting the stock solution. The $\mathrm{pH}$ value for test solution was adjusted by $0.1 \mathrm{M} \mathrm{HCl}$ and $0.1 \mathrm{M} \mathrm{NaOH}$. A fixed amount of dry adsorbents $0.5 \mathrm{~g}$ was added to a series of capped conical flasks containing $100 \mathrm{~mL}$ of $0.08 \mathrm{mg} \cdot \mathrm{L}^{-1} \mathrm{~K}_{2} \mathrm{Cr}_{2} \mathrm{O}_{7}$ solution and shaken at $100 \mathrm{rpm}$ using a constant temperature bath oscillator (SHA-C, China). A number of experimental variables such as adsorbent dosage (0.1 - 4 g), contact time (10 - $240 \mathrm{~min}), \mathrm{pH}(2-12)$ and temperature $\left(25^{\circ} \mathrm{C}-45^{\circ} \mathrm{C}\right)$ which affect the adsorption process have been studied to investigate the removal process. After shaking for a period of predetermined time, the solutions were allowed to settle for $10 \mathrm{~min}$ and the samples were centrifuged at $3000 \mathrm{rpm}$ for $10 \mathrm{~min}$. Concentrations of hexavalent chromium in the filtrate were determined spectrophotometrically using diphenylcarbazide solution at $\lambda=540 \mathrm{~nm}$.

The amount of hexavalent chromium adsorbed per unit mass of the adsorbent $\left(\mathrm{Q}_{\mathrm{e}}\right)$ was computed by using the following expression:

$$
\mathrm{Q}_{\mathrm{e}}=\left[\mathrm{V}\left(\mathrm{C}_{0}-\mathrm{C}_{\mathrm{e}}\right)\right] / \mathrm{m}
$$

where $\mathrm{C}_{0}\left(\mathrm{mg} \cdot \mathrm{L}^{-1}\right)$ and $\mathrm{C}_{\mathrm{e}}\left(\mathrm{mg} \cdot \mathrm{L}^{-1}\right)$ are the initial and final concentrations of hexavalent chromium in the aqueous solutions $\left(\mathrm{mg} \cdot \mathrm{L}^{-1}\right)$, respectively. $\mathrm{V}$ is the solution volume $(\mathrm{mL})$ and $\mathrm{m}$ is the amount of adsorbent $(\mathrm{g})$.

The adsorption efficiency was determined as below: 


$$
\eta=\left[\left(\mathrm{C}_{0}-\mathrm{C}_{\mathrm{e}}\right) / \mathrm{C}_{0}\right] * 100
$$

where $\eta$ is the adsorption efficiency of hexavalent chromium on ARM (\%). The average of adsorption efficiency with three repeats was reported in this study.

\section{Result and Discussion}

\subsection{Characterizations of ARM}

The RM and ARM were observed by scanning electron microprobe at 10,000× magnification. The SEM images in Figure 1 may provide visual evidence of the effect of on the RM surface erosion and collapse. When RM was treated with $\mathrm{HCl}$, the oxides of iron, calcium, sodium and aluminum are converted to their respective chlorides. Calcium and some other acid-soluble salts were partially dissolved, and then some coarse exterior and new cavities appeared during the RM acidification process [20]. The acidic surface treatments lead to the development of micropores or mesopores on the RM surface and create localized adsorption sites on the RM surface [21]. It is the reason why the acidic treatment could result in a greater specific surface area and porosity.

Figure 2 displays the X-ray diffraction of the RM before and after modification. In RM, the major phases are hematite, Hydrogrossular and cancrinte. The XRD pattern of ARM revealed that the peak intensities of other mineral phases were decreased prominently whereas the intensity of hematite peak remains constant.

The XRF analysis was carried out to know the chemical compositions of the RM and the subsequent chemical changes that occurred due to acid treatment. The chemical composition of ARM was also listed in Table 1. In which the contents of partial mental oxides are decreased. We can know that RM contains more metal oxides than ARM. Kasliwal and Sai [22] had reported that the RM surface is treated with $\mathrm{HCl}$ to investigate a method for enrichment of titanium dioxide in RM. It is observed that the fractional conversions of calcium, iron and sodium increase with an increase in acid to red mud ratio.

The results of other activated red mud on the adsorption of hexavalent chromium are compared with literature data [23] in Table 2. Based on the results, it could conclude that heat-acid activated red mud had a significant potential for removing hexavalent chromium from wastewater using adsorption method.

\subsection{Mechanism of Adsorption of Hexavalent Chromium on ARM}

The red mud has a great potential for hexavalent chromium removing due to its chemical stability, mechanical stability and structural properties. Compared with other materials, red mud contains lots of iron, aluminum metal oxides and hydroxides. These substances provides material base for the adsorption of hexavalent chromium. In a

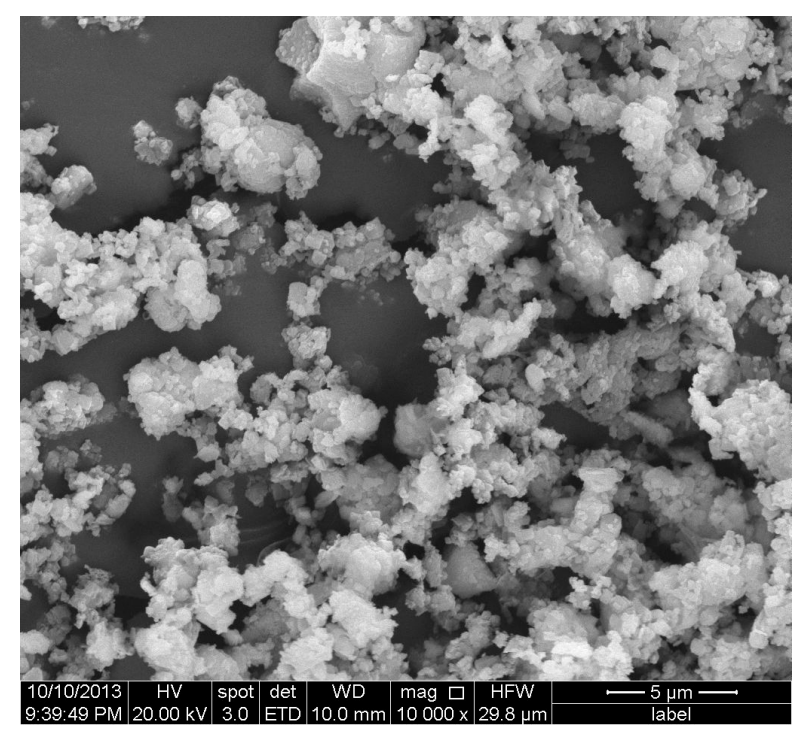

(a)

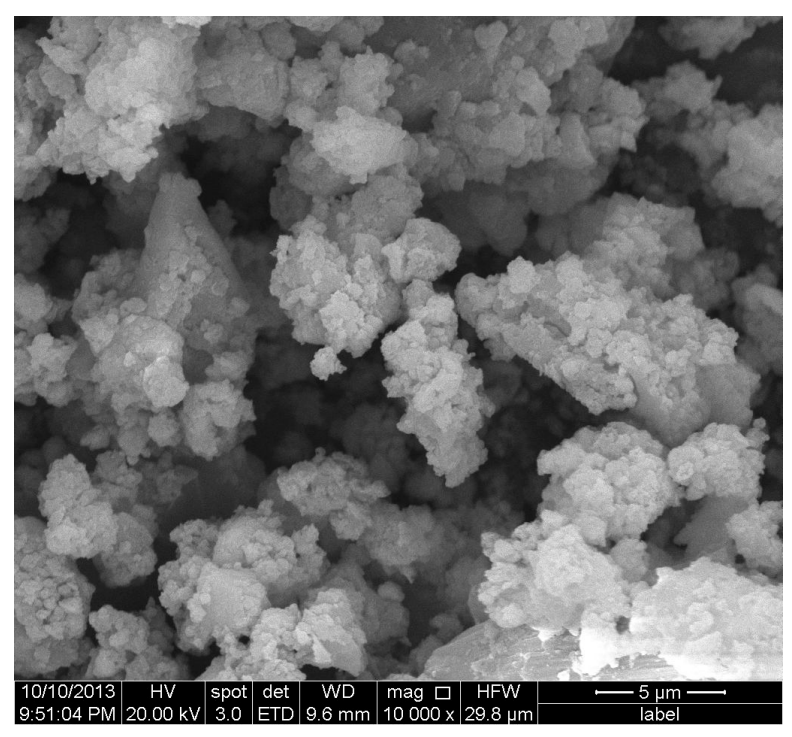

(b)

Figure 1. SEM images of RM (a) and RAM (b). 


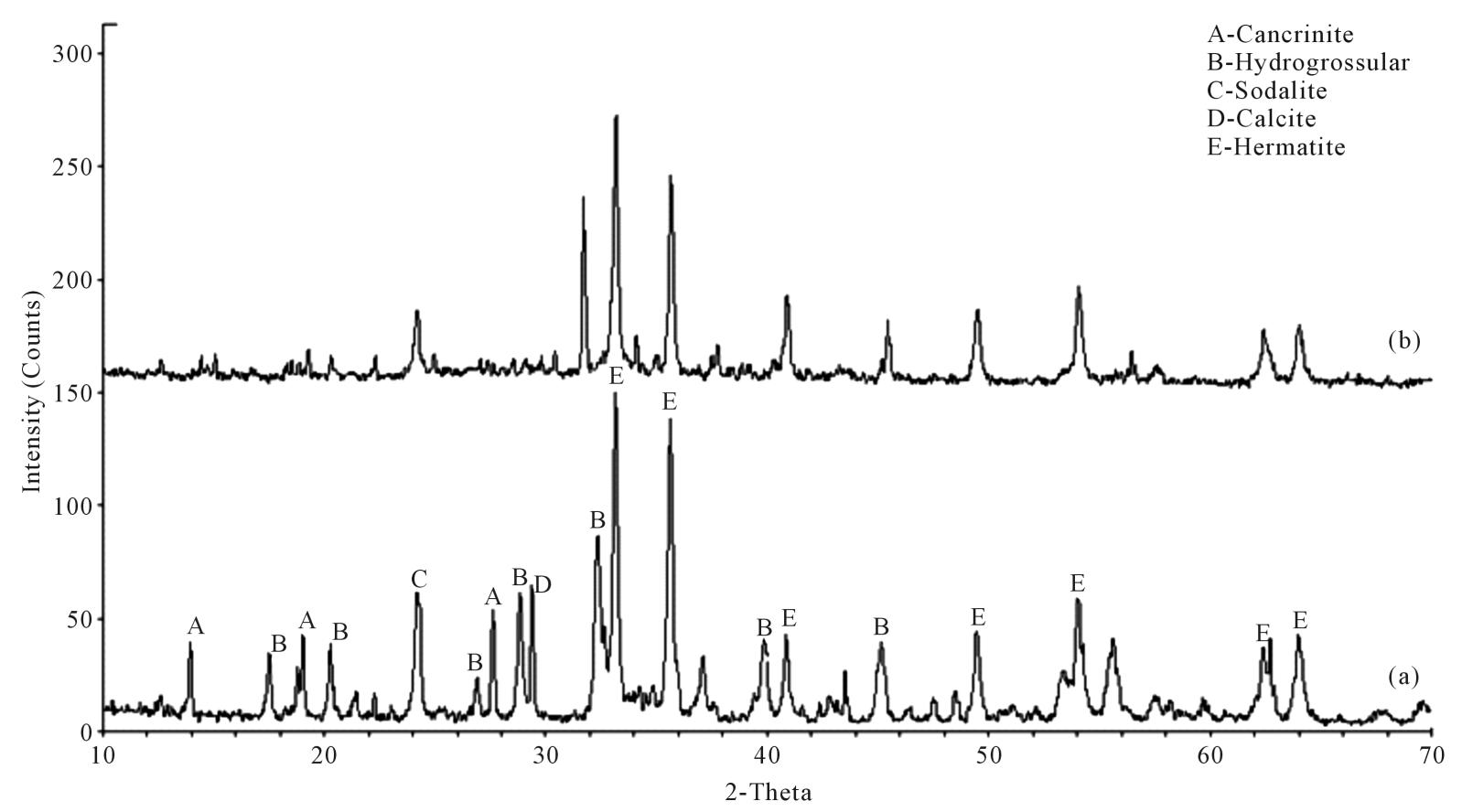

Figure 2. X-ray diffraction of RM (a) and ARM (b).

Table 1. The chemical composition of RM after modification (\%).

\begin{tabular}{ccccccccc}
\hline Component & $\mathrm{SiO}_{2}$ & $\mathrm{Fe}_{2} \mathrm{O}_{3}$ & $\mathrm{Al}_{2} \mathrm{O}_{3}$ & $\mathrm{CaO}$ & $\mathrm{MgO}$ & $\mathrm{K}_{2} \mathrm{O}$ & $\mathrm{Na}_{2} \mathrm{O}$ \\
\hline Amount & 8.72 & 30.6 & 13.66 & 8.09 & 0.63 & 0.014 & 2.30 \\
\hline
\end{tabular}

Table 2. The adsorption hexavalent on different activated red mud.

\begin{tabular}{ccc}
\hline Adsorbent & Initial concentration $\left(\mathrm{mg} \cdot \mathrm{L}^{-1}\right)$ & Adsorption efficiency (\%) \\
\hline Heat-acid activate red mud & 0.08 & 92.21 \\
Acid activate red mud & 0.08 & 84.23 \\
$\mathrm{H}_{2} \mathrm{O}_{2}$ activate red mud & 0.08 & -18 \\
Calcined red mud $\left(400^{\circ} \mathrm{C}\right)$ & 0.08 & -37.12 \\
${\mathrm{Calcined} \mathrm{red} \mathrm{mud}\left(600^{\circ} \mathrm{C}\right)}^{\mathrm{FeCl}_{3} \cdot 6 \mathrm{H}_{2} \mathrm{O} \text { activate red mud }}$ & 0.08 & -204.73 \\
$\mathrm{AlCl}_{3} \cdot 6 \mathrm{H}_{2} \mathrm{O}$ activate red mud & 0.08 & 96.18 \\
$\mathrm{CaCl}_{2}$ activate red mud & 0.08 & 43.54 \\
$1 \% \mathrm{CTAB}$ activate red mud & 0.08 & 13.03 \\
$1 \% \mathrm{SDBS}$ activate red mud & 0.08 & 14 \\
\hline
\end{tabular}

humid environment, hydroxylated surfaces of these oxides developed charge on the surface. When the red mud was added into a solution, there exists such surface hydrolysis reactions depending on $\mathrm{pH}$ [24]-[26]:

$$
\begin{gathered}
\equiv \mathrm{SOH}+\mathrm{H}^{+} \leftrightharpoons \equiv \mathrm{SOH}_{2}^{+} \\
\equiv \mathrm{SOH} \leftrightharpoons \mathrm{SO}+\mathrm{H}^{+}
\end{gathered}
$$

At $\mathrm{pH}$ 2, the species of hexavalent chromium that predominates is $\mathrm{HCrO}_{4}^{-}$, which can react to ARM as follows: 


$$
\begin{gathered}
\equiv \mathrm{SOH}_{2}^{+}+\mathrm{HCrO}_{4}^{-} \leftrightharpoons \equiv \mathrm{SOH}_{2}^{+}-\mathrm{HCrO}_{4}^{-} \\
\equiv \mathrm{SOH}_{2}^{+}+\mathrm{HCrO}_{4}^{-} \leftrightharpoons \mathrm{SHCrO}_{4}+\mathrm{H}_{2} \mathrm{O}
\end{gathered}
$$

On the other hand the adsorption of hexavalent chromium on the ARM is $94.26 \%$ at $\mathrm{pH}$ 2. Because, at lower $\mathrm{pH}$, the solution $\mathrm{pH}$ values below the $\mathrm{pH}_{\mathrm{pzc}}$ of the adsorber, the surface of adsorber particles is positively charged. The ARM surface is positively charged, it can absorb $\mathrm{HCrO}_{4}^{-}$ion.

This implied that the adsorption processes of hexavalent chromium were neither purely physical nor chemical processes, but a combination of the two processes. The possible adsorptions between the ARM and hexavalent chromium are electrostatic attraction and ligand exchange [27] [28]. The results are very similar to those reported by Erdem in his study of hexavalent chromium remove by using heat-activated bauxite [29].

\subsection{Adsorption of Hexavalent Chromium on ARM}

\subsubsection{Effect of Adsorbent Dosage}

Adsorbent dosage is an important parameter because it determines the capacity of an adsorbent for a given initial concentration of the adsorbate. The effect of adsorbent has been studied on hexavalent chromium removal and the results have been illustrated in Figure 3(a). In general, the increase in adsorbent dosage increased the percent removal of adsorbate. As the adsorbent dosage was increased from 0.1 to $0.5 \mathrm{~g}$, the hexavalent chromium adsorption efficiency increased from $6.69 \%$ to $18.35 \%$ for RM. Because number of active sites increases with respect to increase of adsorbent dosage. However, the hexavalent chromium adsorption efficiency was decreased when the adsorbent dosage was more than $0.5 \mathrm{~g}$. The adsorbent dosage increase can lead to the $\mathrm{pH}$ of the test solution being increased, and high $\mathrm{pH}$ is not conducive for hexavalent chromium adsorption. Under the same conditions, the hexavalent chromium maximum adsorption efficiency of ARM reached $92.21 \%$. This was because acid treatment RM can increase specific surface area and porosity. Taking into account the above results, the dosage of hexavalent chromium adsorption was set as $0.5 \mathrm{~g}$ in the following experiments.

\subsubsection{Effect of Contact Time}

The important findings were represented in Figure 3(b) which revealed that, hexavalent chromium adsorption efficiency increases with increasing contact time until the state of equilibrium is reached. It was clear that the removal of hexavalent chromium can be derived into two stages: the first stage showed high adsorption efficiency is very high, followed by a second stage with much lower adsorption efficiency. At a contact time of 120 min, $92.34 \%$ greater maximum sorption occurred. Thus, a period of 120 minis is adequate for adsorption of hexavalent chromium onto ARM.

\subsubsection{Effect of $\mathrm{pH}$}

The solution $\mathrm{pH}$ is another important parameter and it has a strong effect on the adsorption of hexavalent chromium on the surface of the ARM. Hexavalent chromium can be represented in various forms such as $\mathrm{H}_{2} \mathrm{CrO}_{4}$, $\mathrm{HCrO}_{4}^{-}, \mathrm{Cr}_{2} \mathrm{O}_{7}^{2-}$ and $\mathrm{CrO}_{4}^{2-}$ depending on the $\mathrm{pH} . \mathrm{H}_{2} \mathrm{CrO}_{4}$ predominates at $\mathrm{pH}$ less than about 1.0. While in the $\mathrm{pH}$ range of $1-6$ different forms of chromium ions such as $\mathrm{HCrO}_{4}^{-}$and $\mathrm{Cr}_{2} \mathrm{O}_{7}^{2-}$ coexist, being $\mathrm{HCrO}_{4}^{-}$ predominant. As the $\mathrm{pH}$ increases, this form shifts to $\mathrm{Cr}_{2} \mathrm{O}_{7}^{2-}$ and $\mathrm{CrO}_{4}^{2-}$. At $\mathrm{pH}$ greater than $7.5, \mathrm{CrO}_{4}^{2-}$ is the only hexavalent chromium species in aqueous phase [30]. The existing balances among different ionic species of hexavalent chromium are given as follows:

$$
\begin{aligned}
\mathrm{H}_{2} \mathrm{CrO}_{4} & \leftrightharpoons \mathrm{HCrO}_{4}^{-}+\mathrm{H}^{+} \\
\mathrm{HCrO}_{4}^{-} & \leftrightharpoons \mathrm{CrO}_{4}^{2-}+\mathrm{H}^{+} \\
2 \mathrm{HCrO}_{4}^{-} & \leftrightharpoons \mathrm{Cr}_{2} \mathrm{O}_{7}^{2-}+\mathrm{H}_{2} \mathrm{O}
\end{aligned}
$$

The solution $\mathrm{pH}$ relative to the point of zero charge $\left(\mathrm{pH}_{\mathrm{pzc}}\right)$ for the ARM also needs to be considered. At $\mathrm{pH}$ values below the $\mathrm{pH}_{\mathrm{pzc}}$ of the adsorber, the surface of adsorber particles is positively charged and as the $\mathrm{pH}$ rises above the $\mathrm{pH}_{\mathrm{pzc}}$, anion adsorption decreases. The $\mathrm{pH}_{\mathrm{pzc}}$ for activated red mud has been reported as about 8.5 in Ref. [31]. The maximum adsorption efficiency of hexavalent chromium was obtained at $\mathrm{pH} 2$ while the adsorption decreased when the $\mathrm{pH}$ increased as can be observed in Figure 3(c). The decrease of adsorption efficiency 
in the alkaline $\mathrm{pH}$ range $(\mathrm{pH}>8.5)$ may be due to the competition of the $\mathrm{OH}^{-}$with the hexavalent chromium for surface sites on ARM or electrostatic repulsion of hexavalent chromium ion to the negatively charged surface. A similar type of behavior was also reported for the adsorption of hexavalent chromium on bauxite tailing [32] and montmorillonite [33].

\subsubsection{Effect of Reaction Temperature and Thermodynamic Parameters}

Temperature dependence of the adsorption process is associated with several thermodynamic parameters. It was observed in Figure 3(d) that the hexavalent chromium adsorption efficiency decreases with increasing temperature and maximum adsorption of hexavalent chromium was obtained the temperature of the solution at $30^{\circ} \mathrm{C}$.

In order to study the feasibility of the adsorption process, the change in free energy $(\Delta \mathrm{G})$, enthalpy $(\Delta \mathrm{H})$ and entropy $(\Delta \mathrm{S})$ of adsorption were calculated by using the following equations [34]:

$$
\begin{gathered}
\mathrm{KD}=\mathrm{Q}_{\mathrm{e}} / \mathrm{C}_{\mathrm{e}} \\
\Delta \mathrm{G}=-\mathrm{RT} \ln \mathrm{KD} \\
\Delta \mathrm{G}=\Delta \mathrm{H}-\mathrm{T} \Delta \mathrm{S}
\end{gathered}
$$

where $\mathrm{Q}_{\mathrm{e}}$ and $\mathrm{C}_{\mathrm{e}}$ represent the concentration $\left(\mathrm{mg} \cdot \mathrm{L}^{-1}\right)$ of hexavalent chromiumon adsorbent and in solution, $\mathrm{KD}$ is the distribution coefficient, $\mathrm{R}$ is the universal gas constant $\left(8.314 \mathrm{~J} \cdot \mathrm{mol}^{-1} \cdot \mathrm{K}^{-1}\right)$ and $\mathrm{T}$ is the absolute temperature (K). Thermodynamic parameters, $\Delta \mathrm{H}$ and $\Delta \mathrm{S}$ were calculated from the slope and intercept of the plot of

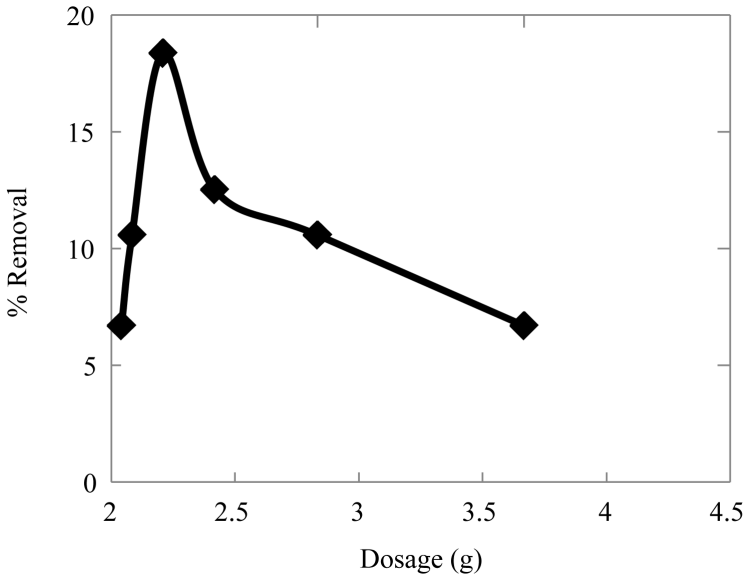

(a)

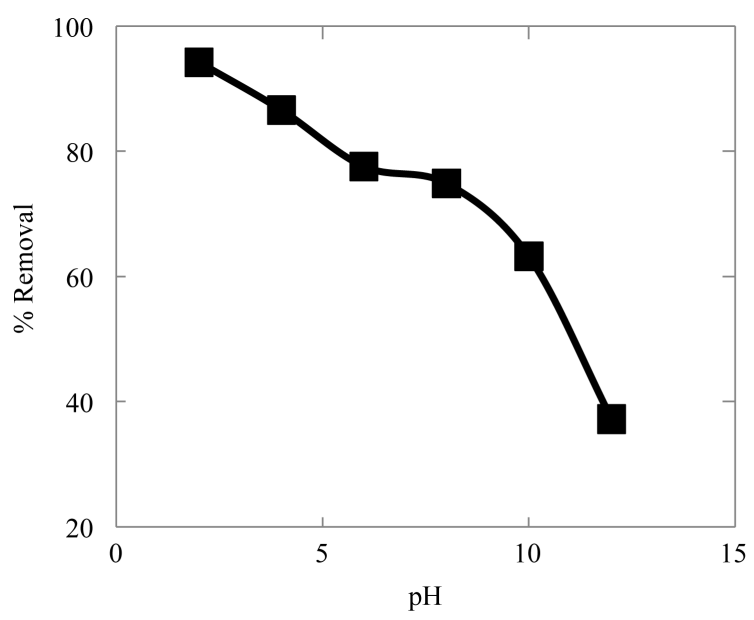

(c)

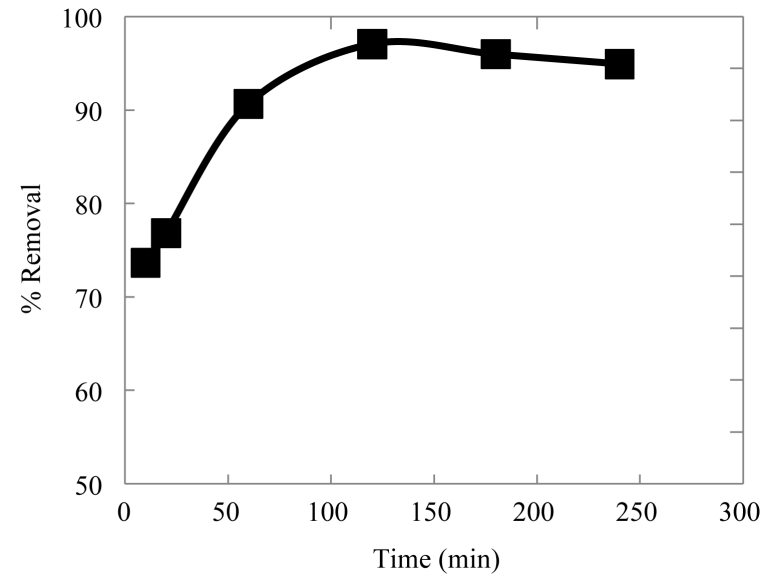

(b)

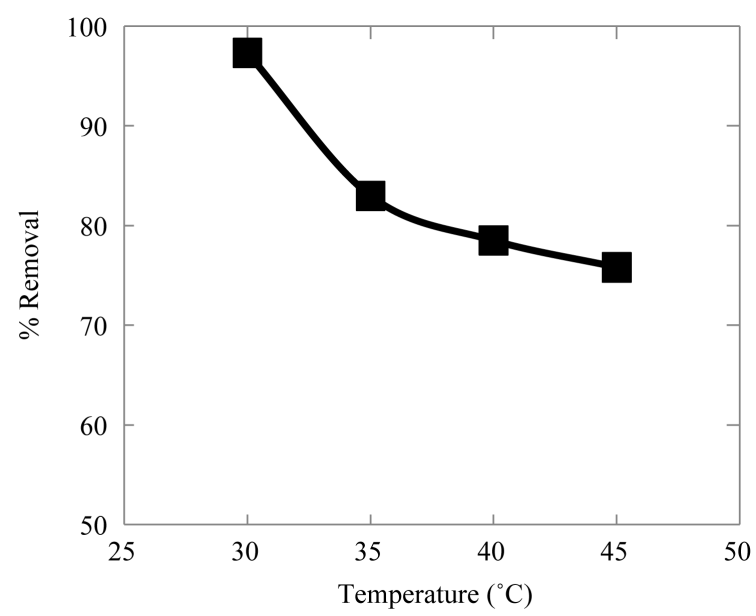

(d)

Figure 3. Effect of adsorbent dosage (a), contact time (b), $\mathrm{pH}$ (c) and the reaction temperature (d) on hexavalent chromium adsorption percentage. 
$\operatorname{lnKd}$ against $1 / \mathrm{T}$. Values of $\Delta \mathrm{H}, \Delta \mathrm{G}$ and $\Delta \mathrm{S}$ are represented in Table 3 . The positive values of $\Delta \mathrm{G}$ indicate that the sorption of hexavalent chromium onto ARM was not spontaneous processes. Enthalpy change of absolute value of chemical adsorption is greater than $20 \mathrm{~kJ} \cdot \mathrm{mol}^{-1}$ [35]. The enthalpy change $\Delta \mathrm{H}$ had a value of 123.31 $\mathrm{kJ} \cdot \mathrm{mol}^{-1}$ for the adsorption of hexavalent chromium, and it suggests that hexavalent chromium adsorbs onto ARM in the form of chemical adsorption. The negative $\Delta S$ values signify there is a decrease in therandomnessat the solid-solution interface of hexavalent chromium onto ARM.

\subsection{Adsorption Isotherms}

Langmuir and Freundlich isotherm equations are used to establish the relationship between the amount of hexavalent chromium adsorbed by ARM and their equilibrium concentration in aqueous solutions. These isotherms are as follows:

1) Langmuir isotherm

$$
\mathrm{Q}_{\mathrm{e}}=\mathrm{Q}_{\max } \mathrm{K}_{\mathrm{L}} \mathrm{C}_{\mathrm{e}} /\left(1+\mathrm{K}_{\mathrm{L}} \mathrm{C}_{\mathrm{e}}\right)
$$

where $\mathrm{K}_{\mathrm{L}}$ is the Langmuir adsorption constant $\left(\mathrm{L}^{\mathrm{mg}} \mathrm{m}^{-1}\right)$ and $\mathrm{Q}_{\max }$ is the monolayer adsorption capacity of the adsorbent $\left(\mathrm{mg} \cdot \mathrm{g}^{-1}\right)$. Langmuir adsorption isotherm equation assumes that adsorption occurs at specific homogeneous sites within the adsorbent.

2) Freundlich isotherm

$$
\mathrm{Q}_{\mathrm{e}}=\mathrm{K}_{\mathrm{F}} \mathrm{C}_{\mathrm{e}}^{1 / \mathrm{n}}
$$

where $\mathrm{K}_{\mathrm{F}}\left(\mathrm{L} \cdot \mathrm{mg}^{-1}\right)$ and $\mathrm{n}$ are Freundlich constants related to adsorption capacity and adsorption intensity, respectively. Freundlich adsorption isotherm equation assumes a heterogeneous adsorption surface with sites that have different energies of adsorption and are not equally available.

It can be seen from Table 4 and Figure 4 that the Langmuir isotherm equation better fitted than the Freundlich isotherm equation by comparing the results of correlation coefficient values. This was due to homogenous distribution of active sites on the ARM surface, since the Langmuir isotherm equation assumes that the surface is homogeneous. The monolayer adsorption capacity of ARM was found as $0.03 \mathrm{mg} \cdot \mathrm{g}^{-1}$. In order to calculate the adsorption efficiency of the adsorption process and to know whether the process is favorable or unfavorable for

Table 3. Thermodynamics parameters of hexavalent chromium adsorption onto ARM.

\begin{tabular}{ccccc}
\hline & \multicolumn{4}{c}{$\Delta \mathrm{G}\left(\mathrm{kJ} \cdot \mathrm{mol}^{-1}\right)$} \\
$\mathrm{H}\left(\mathrm{kJ} \cdot \mathrm{mol}^{-1}\right)$ & $303.15 \mathrm{~K}$ & $308.15 \mathrm{~K}$ & $313.15 \mathrm{~K}$ & $318.15 \mathrm{~K}$ \\
\cline { 2 - 5 } & 242.96 & 244.93 & 246.90 & 248.88 \\
\hline
\end{tabular}

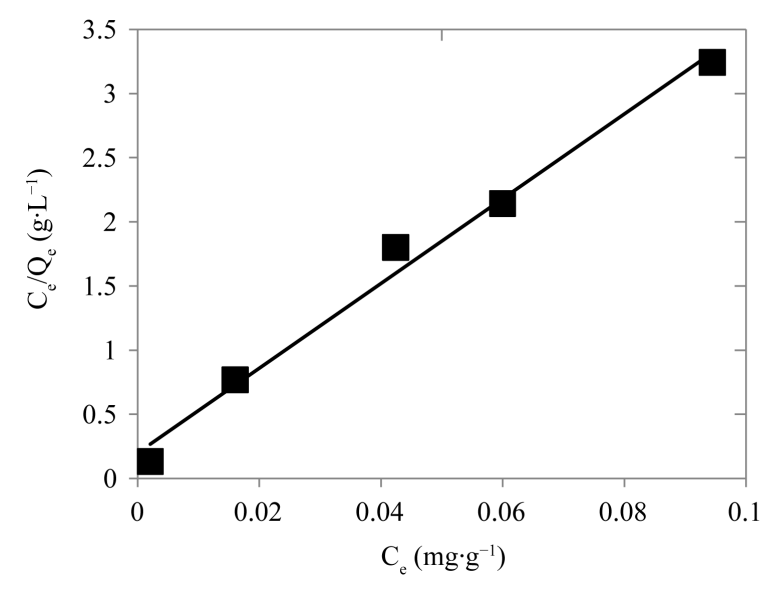

(a)

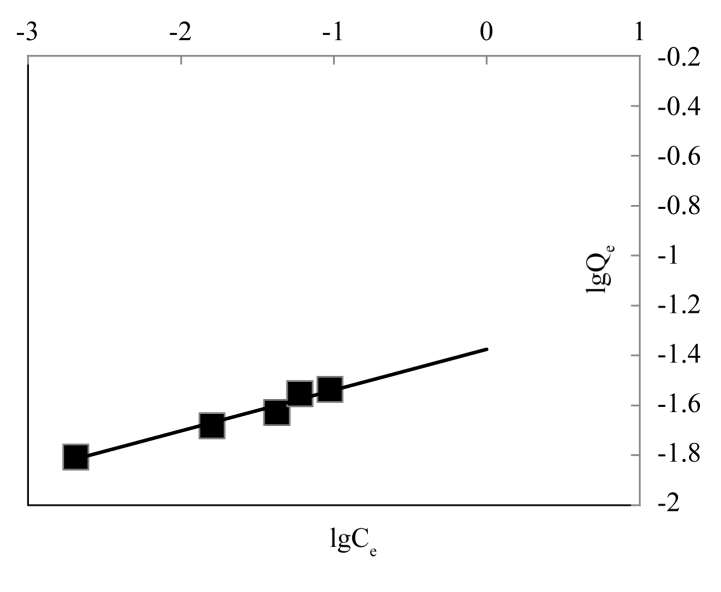

(b)

Figure 4. Langmuir (a) and Freundlich (b) plots for the adsorption of hexavalent chromium onto ARM. 
Table 4. Langmuir and Freundlich constants and correlation coefficient of the adsorption of hexavalent chromium onto ARM.

\begin{tabular}{cccccc}
\hline & Langmuir equation & & \multicolumn{3}{c}{ Freundlich equation } \\
\hline $\mathrm{Q}_{\max }\left(\mathrm{mg} \cdot \mathrm{g}^{-1}\right)$ & $\mathrm{K}_{\mathrm{L}}\left(\mathrm{L} \cdot \mathrm{mg}^{-1}\right)$ & $\mathrm{R}^{2}$ & $\mathrm{~K}_{\mathrm{F}}\left(\mathrm{L} \cdot \mathrm{mg}^{-1}\right)$ & $\mathrm{n}$ & $\mathrm{R}^{2}$ \\
\hline 0.03 & 165.78 & 0.988 & 0.042 & 6.135 & 0.967 \\
\hline
\end{tabular}

the Langmuir type adsorption, the dimensionless equilibrium parameter $\left(\mathrm{R}_{\mathrm{L}}\right)$ was calculated using the Langmuir adsorption constant obtained from the Langmuir isotherm as follows:

$$
\mathrm{R}_{\mathrm{L}}=1 /\left(1+\mathrm{K}_{\mathrm{L}} \mathrm{C}_{0}\right)
$$

where $C_{0}$ is the initial hexavalent chromium concentration $\left(\mathrm{mg} \cdot \mathrm{L}^{-1}\right)$. As the $\mathrm{R}_{\mathrm{L}}$ values lie between 0 and 1 , the adsorption process is favorable [36]. The calculated $\mathrm{R}_{\mathrm{L}}$ values found in this study are between 0.07 and 0.0245 for 0.08 - $0.24 \mathrm{mg} \cdot \mathrm{L}^{-1}$ concentration of hexavalent chromium adsorption onto ARM, representing favorable adsorption process.

\subsection{Research Prospects}

Due to limitations in experimental conditions, there is a lot of research to be done. This study selects the static adsorption experiment to explore the performance of the adsorbent. But in actual situation, wastewater is usually continuous flow. So the performance of the adsorbent could be differences in practical engineering application. Adsorbent regeneration performance determines the practical application value of adsorbent. Research on adsorbent regeneration performance evaluation has not been carried out, in the subsequent experiments, regeneration and reuse of adsorbents will be the focus of research.

\section{Conclusions}

The present work shows that thermally activated acid neutralized red mud can be used as adsorbent for the removal of hexavalent chromium from aqueous solutions successfully. SEM image indicated clearly the structural transformation of the RM after modified. The XRD and XRF studies revealed that RM contains significantly more metal ions than ARM. All the characteristics analysis indicated the successful modification of RM. The ARM has shown good adsorptivity for hexavalent chromium. For the solution of $0.08 \mathrm{mg} \cdot \mathrm{L}^{-1}$, the maximum adsorption yield is found as $97.31 \%$ when $0.5 \mathrm{~g}$ sorbent was added in solution at $\mathrm{pH} 2$ and temperature: $30^{\circ} \mathrm{C}$. The adsorption efficiency decreased with an increase in temperature indicated that the adsorption process was exothermic. The experimental data fitted well with Langmuir isotherm equation, as the homogenous adsorption occurred. Adsorption of hexavalent chromium on ARM is a result of the electrostatic attraction and ligand exchange.

Additionally, the red mud is discarded as waste in bauxite processing industry, its utilization as adsorbent for removal of hexavalent chromium is expected to be economical. The results of this study indicated that ARM has the potential to be used as an alternative adsorbent material for the removal of hexavalent chromium from water.

\section{References}

[1] Altundogan, H.S. (2005) Cr(VI) Removal from Aqueous Solution by Iron(III) Hydroxide-Loaded Sugar Beet Pulp. Process Biochemistry, 40, 1443-1452. http://dx.doi.org/10.1016/S0093-6413(02)00223-9

[2] Xu, H.J., Huang, R.L., Li, T.J., Kong, X.F. and Yin, Y.L. (2010) Nutritional and Physiological Functions of Chromium. Natural Product Research and Development, 3, 531-534.

[3] Zhitkovich, A., Vitkun, V. and Costa, M. (1996) Formation of the Amino Acid-DNA Complexs by Hexavalent and Trivalent Chromium in Vitro: Importance of Trivalent Chromium and Phosphate Group. Biochemistry, 35, 7275-7282. http://dx.doi.org/10.1021/bi960147w

[4] Kotaś, J. and Stasicka, Z. (2000) Chromium Occurrence in the Environment and Methods of Its Speciation. Environmental Pollution, 107, 263-283. http://dx.doi.org/10.1016/S0269-7491(99)00168-2

[5] Owlad, M., Aroua, M.K., Daud, W.A.W. and Baroutian, S. (2009) Removal of Hexavalent Chromium-Contaminated Water and Wastewater: A Review. Water Air Soil Pollution, 200, 59-77. http://dx.doi.org/10.1007/s11270-008-9893-7 
[6] Zhang, Z.J., Li, L., Zhu, H., Wang, F.F and Hua, J. (2008) Removing Chromium from Electroplating Wastewater by Chemical Precipitation. Environmental Science and Technology, 31, 96-97.

[7] Kumbasar, R.A. (2008) Selective Separation of Chromium (VI) from Acidic Solutions Containing Various Metal Ions through Emulsion Liquid Membrane Using Trioctylamine as Extractant. Separation and Purification Technology, 64, 56-62. http://dx.doi.org/10.1007/s11270-008-9893-7

[8] Rengaraj, S., Yeon, K.H. and Moon, S.H. (2001) Removal of Chromium from Water and Wastewater by Ion Exchange Resins. Hazardous Materials, 87, 273-287. http://dx.doi.org/10.1016/S0304-3894(01)00291-6

[9] Chaudhary, A.J., Goswami, N.C. and Grimes, S.M. (2003) Electrolytic Removal of Hexavalent Chromium from Aqueous Solutions. Journal of Chemical Technology and Biotechnology, 78, 877-833. http://dx.doi.org/10.1002/jctb.871

[10] Wang, J.H., Chang, E., Ding, S.L. and Zheng, C.L. (2012) Advance in Adsorptive Removal of Cr(VI) from Aqueous Solutions. Environmental Science and Technology, 35, 67-72.

[11] Natale, F.D., Lancia, A., Molino, A. and Musmarra, D. (2007) Removal of Chromium Ions from Aqueous Solutions by Adsorption on Activated Carbon and Char. Hazardous Materials, 145, 381-390. http://dx.doi.org/10.1016/j.jhazmat.2006.11.028

[12] Ramos, R.L., Azuara, A.J., Flores, P.E.D., Coronado, R.M.G., Barron, J.M. and Mendoza, M.S.B. (2008) Adsorption of Chromium(VI) from an Aqueous Solution on a Surfactant-Modified Zeolite. Collioids and Surfaces A: Physicochemical and Enigineering Aspects, 330, 35-41. http://dx.doi.org/10.1016/j.colsurfa.2008.07.025

[13] Tewari, N., Guha, B.K. and Asudevan, P.V. (2005) Adsorption Study of Hexavalent Chromium by Bentonite Clay. Asian Journal of chemistry, 17, 2184-2190.

[14] Şahin, Y. and Öztürk, A. (2005) Biosorption of Chromium(VI) Ions from Aqueous Solution by the Bacterium Bacillus thuringiensis. Process Biochemistry, 40, 1895-1901. http://dx.doi.org/10.1016/j.procbio.2004.07.002

[15] Banerjee, S.S., Joshi, M.V. and Jayaram, R.V. (2005) Removal of Cr(VI) and Hg(II) from Aqueous Solutions Using Fly Ash and Impregnated Fly Ash. Separation Science and Technology, 39, 1611-1629. http://dx.doi.org/10.1081/SS-120030778

[16] Pradhan, J., Das, S.N. and Thakur, R.S. (1999) Adsorption of Hexavalent Chromium from Aqueous Solution by Using Activated Red Mud. Colloid and Interface Science, 217, 137-141. http://dx.doi.org/10.1006/jcis.1999.6288

[17] Li, Y.Z., Liu, C.J., Luan, Z.K., Peng, X.J., Zhu, C.L., Chen, Z.Y., Zhang, Z.G., Fan, J.H. and Jia, Z.P. (2006) Phosphate Removal from Aqueous Solutions Using Raw and Activated Red Mud and Fly Ash. Hazardous Materials, 137, 374-383. http://dx.doi.org/10.1016/j.jhazmat.2006.02.011

[18] Wang, S.B., Boyjoo, Y., Choueib, A. and Zhu, Z.H. (2005) Removal of Dyes from Aqueous Solution Using Fly Ash and Red Mud. Water Research, 39, 129-138. http://dx.doi.org/10.1016/j.watres.2004.09.011

[19] Luan, Z.K., Li, Y.Z., Chen, Z.Y., Zhang, Z.G. and Jia, Z.P. (2007) High Activity of Red Mud Adsorbents and Its Preparation Method. Chinese Patent No. 1981921.

[20] Liu, C.J., Li, Y.Z., Luan, Z.K., Chen, Z.Y., Zhang, Z.G. and Jia, Z.P. (2007) Adsorption Removal of Phosphate from Aqueous Solution by Active Red Mud. Journal of Environmental Sciences, 19, 1166-1170. http://dx.doi.org/10.1016/S1001-0742(07)60190-9

[21] Park, S.J., Seo, D.I. and Nah, C. (2002) Effect of Acidic Surface Treatment of Red Mud on Mechanical Interfacial Properties of Epoxy/Red Mud Nanocomposites. Journal of Colloid and Interface Science, 251, 225-229. http://dx.doi.org/10.1006/jcis.2002.8336

[22] Kasliwal, P.K. and Sai, P.S.T. (1999) Enrichment of Titanium Dioxide in Red Mud: A Kinetic Study. Hydrometallurgy, 53, 73-87. http://dx.doi.org/10.1016/S0304-386X(99)00034-1

[23] Han, Y. (2004) Study on Preparation and Application of Red Mud Adsorbent Material. Master Thesis, Beijing University of Chemical Technology, Beijing.

[24] Goldberg, S. and Sposito, G. (1985) On the Mechanism of Specific Phosphate Adsorption by Hydroxylated Mineral Surfaces: A Review. Communications in Soil Science and Plant Analysis, 16, 801-821. http://dx.doi.org/10.1080/00103628509367646

[25] Altundoğan, H.S. and Tümen, F. (2002) Removal of Phosphates from Aqueous Solutions by Using Bauxite. I: Effect of $\mathrm{pH}$ on the Adsorption of Various Phosphates. Chemical Technology and Biotechnology, 77, 77-85. http://dx.doi.org/10.1002/jctb.525

[26] Altundoğan, H.S. and Tümen, F. (2003) Removal of Phosphates from Aqueous Solutions by Using Bauxite II: The Activation Study. Journal of Chemical Technology and Biotechnology, 78, 824-833. http://dx.doi.org/10.1002/jctb.860

[27] Pradhan, J., Das, J., Das, S. and Thakur, R.S. (1998) Adsorption of Phosphate from Aqueous Solution Using Activated Red Mud. Journal of Colloid and Interface Science, 204, 169-172. http://dx.doi.org/10.1006/jcis.1998.5594 
[28] Vinitnantharat, S., Kositchaiyong, S. and Chiarakorn, S. (2010) Removal of Fluoride in Aqueous Solution by Adsorption on Acid Activated Water Treatment Sludge. Applied Surface Science, 256, 5458-5462. http://dx.doi.org/10.1016/j.apsusc.2009.12.140

[29] Erdem, M., Altundoğan, H.S. and Tümen, F. (2004) Removal of Hexavalent Chromium by Using Heat-Activated Bauxite. Minerals Engineering, 17, 1045-1052. http://dx.doi.org/10.1016/j.mineng.2004.04.013

[30] Mohan, D. and Pittman Jr., C.U. (2006) Activated Carbons and Low Cost Adsorbents for Remediation of Tri- and Hexavalent Chromium from Water. Hazardous Materials, 137, 762-811. http://dx.doi.org/10.1016/j.jhazmat.2006.06.060

[31] Gupta, V.K., Gupta, M. and Sharma, S. (2001) Process Development for the Removal of Lead and Chromium from Aqueous Solutions Using Red Mud-An Aluminium Industry Waste. Water Research, 35, 1125-1134. http://dx.doi.org/10.1016/S0043-1354(00)00389-4

[32] Wang, Y.H., Lan, Y. and Hu, Y.H. (2008) Adsorption Mechanisms of Cr(VI) on the Modified Bauxite Tailings. Minerals Engineering, 21, 913-917. http://dx.doi.org/10.1016/j.mineng.2008.04.003

[33] Hu, B.J. and Luo, H.J. (2010) Adsorption of Hexavalent Chromium onto Montmorillonite Modified with Hydroxyaluminum and Cetyltrimethylammonium Bromide. Applied Surface Science, 257, 769-775. http://dx.doi.org/10.1016/j.apsusc.2010.07.062

[34] Khan, A.A and Singh, R.P.(1987) Adsorption Thermodynamics of Carbofuran on Sn (IV) Arsenosilicate in $\mathrm{H}^{+}, \mathrm{Na}^{+}$ and $\mathrm{Ca}^{2+}$ forms. Colloids and Surfaces, 24, 33-42. http://dx.doi.org/10.1016/0166-6622(87)80259-7

[35] Gu, B.H., Schmitt, J., Chen, Z.H., Liang, L.Y. and McCarthy J.F. (1994) Adsorption and Desorption of Nature Organic Matter on Iron Oxide: Mechanisms and Models. Enviromental Science and Technology, 8, 38-46. http://dx.doi.org/10.1021/es00050a007

[36] Hall, K.R., Eagleton, L.C., Acrivos, A. and Vermeulen T. (1996) Pore-and Solid-Diffusion Kinetics in Fixed-Bed Adsorption under Constant-Pattern Conditions. Industrial and Engineering Chemistry Fundamentals, 5, 212-223. 